\title{
HUBUNGAN KARAKTERISTIK INDIVIDU DENGAN KOMPETENSI WIRAUSAHA PETANI RUMPUT LAUT DI SULAWESI SELATAN
}

\author{
Relationship Between Personal Characteristics and Enterpreneurship \\ Competencies of Seaweed Farmers in South Sulawesi
}

Syafiuddin dan Amri Jahi

\begin{abstract}
Seaweed farmers are those farmers who have seaweeds farming in rural coastal area, as their moyor income. The objective of this study was to determine the degree of relationship between individual characteristics of seaweed farmers and their entrepreneurship or business competence. Data were collected in July to October2006 from the 280 seaweed farmers. Data were analyzed by Kendal Concordance and Tau_b Path analysis and Pearson procedures. The important results of the study were as follows: (1) most of them are young, low educated, family size is sedentary, low family income, low in media utilization and sedentary in experience, motivation and capital, (2) two groups of competence were perceived (competence-importance) showed that the existence of positive correlation or high agreement, (3) Degree of all individual characteristic showed high positive correlation or high agreement for rank ten component of entrepreneur or business competence, (4) Mostly individual characteristic have significant relationship to entrepreneurship competence with existence of indirect and direct influence to some individual characteristics through entrepreneur or business competence and also direct to productions and incomes of seaweed farmers
\end{abstract}

Key Word: Farmers, Seaweed, Characteristic, Competence, Entrepreneurship.

\section{$\underline{\text { Pendahuluan }}$}

Sulawesi Selatan termasuk daerah yang memiliki panjang garis pantai $2.500 \mathrm{~km}$ dari $81.000 \mathrm{~km}$ yang dimiliki Indonesia. Selain itu Sulawesi Selatan memiliki lebih kurang 250 pulau-pulau kecil yang tersebar di 24 kabupaten. Pada potensi tersebut, di dalamnya terdapat budidaya tambak dan berbagai budidaya perairan umum.

Rumput laut merupakan salah satu sumberdaya kelautan dan perikanan yang selama 5 tahun terakhir mulai dikembangkan oleh masyarakat tani/nelayan di sepanjang pantai karena selain pemeliharaannya mudah juga memiliki keunggulan ekonomis dengan produksi 78.653 ton pada tahun 2003, jumlah petani diperkirakan berkisar 10.000 sampai
15.000 orang dengan luas 144.425 ha. Potensi tersebut di atas tersebar di beberapa daerah di Sulawesi Selatan. Rumput laut merupakan komoditas unggulan di daerah ini di antara 10 komoditas kelautan dan perikanan lain. Tetapi umumnya diakui kualitas komoditas ini masih rendah dan jauh dari yang diharapkan. Tuntutan kebutuhan hidup dan keterikatan petani dengan tengkulak atau pengijon serta kurangnya sarana dan prasarana, menyebabkan petani kurang mampu menghasilkan produk yang lebih baik.

Beberapa kelemahan antara lain karena apresiasi petani terhadap kualitas rumput laut yang rendah. Petani masih lemah pada berbagai aspek terutama pada aspek tehnis budidaya, aspek manajerial atau aspek kewirausahaan. Akibatnya, akses mereka 
untuk memperoleh harga yang lebih baik masih kurang dan hasil produksinya kurang sesuai standar. Berdasarkan latarbelakang tersebut dirumuskan masalah: (1) Bagaimana sebaran petani rumput laut di Sulawesi Selatan pada sejumlah karakteristik individu yang diamati? (2) Kompetensi wirausaha seperti apa, yang dimiliki oleh petani rumput laut? (3) Seberapa besar kesepakatan petani rumput laut tersebut dalam menjenjang kompetensi wirausaha tersebut? (4) Strategi apa yang dapat dikembangkan dalam meningkatkan kapasitas petani pesisir guna mengembangkan usaha rumput laut?

Berdasarkan hal tersebut, tujuan penelitian ini ialah: (1) Menentukan sebaran petani rumput laut di Sulawesi Selatan pada sejumlah karakeristik individu yang diamati, (2) Mengidentifikasi kompetensi wirausaha, yang dikuasai petani rumput di Sulawesi Selatan, (3) Menentukan derajat hubungan kesepakatan petani rumput laut tersebut dalam penjenjangan kompetensi wirausaha, (4) Menemukan strategi yang tepat dalam meningkatkan kapasitas petani pesisir dalam mengembangkan usaha rumput laut.

\section{Metode Penelitian}

\section{$\underline{\text { Populasi }}$}

Populasi penelitian ini adalah petani kepala keluarga di wilayah pesisir yang melakukan usaha budidaya rumput laut di perairan (bukan di tambak). Jumlah petani berdasarkan data yang ada sebanyak 12.430 kepala keluarga (KK). Jumlah petani tersebut menyebar pada daerah Kabupaten Takalar, Jeneponto, Bantaeng, Bulukumba, Sinjai dan Luwu Utara.

\section{$\underline{\text { Sampel }}$}

Sampel diacak di tiga kabupaten yakni Takalar, Jeneponto dan Bantaeng. Ukuran sampel setiap daerah, kecamatan dan desa ditentukan secara proporsional sesuai dengan jumlah petani yang terdapat di desa, kecamatan pada daerah tersebut dan selanjutnya ditentukan secara acak. Besarnya sampel ditentukan sebelumnya dengan menggunakan rumus Slovin. Jumlah sampel dalam penelitian ini berdasarkan rumus adalah sebesar 271,71 atau dibulatkan ke atas menjadi 280. Instrumen penelitian yang telah divalidasi melalui panel pakar di uji coba pada 25 responden petani rumput laut di dusun Punaga Desa Punaga Kecamatan Mangarabombang Kabupaten Takalar Sulawesi Selatan. Hasil uji reliabilitas instrumen dengan Cronbach Alpha untuk 72 item, nilai $\alpha=0,928$ atau instrument dianggap cukup valid dan reliabel sebagai alat ukur. Data primer diperoleh dengan cara (1) pengisian kuesioner (2) wawancara dan pengamatan mendalam (3) FGD.

\section{Analisis Data}

Analisis data dilakukan secara kualitatif dan secara kuantitatif. Untuk menguji hubungan tersebut dilakukan dengan menggunakan analisis korelasi. Uji korelasi dilakukan dengan Uji Konkordansi Kendall W, uji korelasi Kendall Tau_b, dan Path Anaysis

\section{Hasil dan Pembahasan}

$\underline{\text { Hasil }}$

\section{Distribusi Karakteristik Individu Petani Rumput Laut}

Distribusi petani rumput laut perairan pada sejumlah karakteristik yang diamati dari penelitian ini adalah berdasarkan (1) Umur, (2) Pendidikan Formal (3) Tanggungan Keluarga (4) Pengalaman usaha tani (5) Pendapatan Keluarga (6) Motivasi Berusaha (7) Pemanfaatan Media Informasi (8) Luas Lahan Budidaya dan (9) Modal Usaha.

Dua pertiga dari mayoritas petani berumur produktif atau <44 tahun; 89,9 persen berpendidikan formal $>9$ tahun. Tanggungan keluarga rata-rata pada setiap rumah tangga petani yakni 3 orang, sebahagian besar petani 65,8 persen berpendapatan keluarga < Rp 693000 per 
bulan, di antaranya 33,6 persen dengan pendapatan <Rp 391000 perbulan. Sekitar 72,5 persen petani menggunakan media informasi dengan kategori rendah, 88,21 persen memiliki pengalaman usaha $<9$ tahun, 79,3 persen memiliki lahan budidaya $<7500$ $\mathrm{m}^{2}$ dan 64,43 persen dengan modal usaha berkisar Rp 276.000 -Rp 2520.000.

\section{$\underline{\text { Kompetensi Wirausaha Petani }}$}

Kompetensi wirausaha adalah karakteristik mendalam atau perilaku terukur yang dimiliki seseorang berupa tindakan cerdas, bertanggung jawab pada bidang tugasnya yang ditandai dengan motivasi tinggi, penanggungan resiko, melihat dan menilai peluang bisnis dalam mengelola sumberdaya dan memperoleh keuntungan, dan dengan tindakan tersebut ia dianggap mampu oleh masyarakat lain.

Kompetensi wirausaha tersebut pada penelitian ini diklasifikasikan dalam dua kelompok yakni (1) kompetensi wirausaha yang dimiliki petani rumput laut (competence) dan (2) kompetensi wirausaha yang diaggap penting oleh petani rumput laut (importance) Bidang kemampuan pada kompetensi wirausaha tersebut adalah (1) memilih dan menyediakan lokasi (2) pembibitan dan penanaman (3) pemeliharaan (4) panen (5) mengelola pascapanen (6) merencanakan usaha (7) mengorganisasikan dan memasarkan hasil (8) mengambil keputusan, menanggung resiko dan bertindak kreatif (9) berkomunikasi dan memotivasi mengawasi, evaluasi dan mengendalikan usaha

Pada uji hubungan antara kompetensi wirausaha yang dimiliki dan dianggap penting dari 280 petani responden terdapat kesepakatan yang tinggi, ditunjukkan dengan Koefisien korelasi Kendal Tau_b sebesar 0.659 dengan $\alpha=0.009$ yang sangat nyata pada $\alpha=0.01$. Implikasi dari kesepakatan tersebut dapat berarti ada kesesuaian antara kompetensi wirausaha yang dibutuhkan petani dengan kompetensi wirausaha yang dimiliki. Jika ada upaya peningkatan kompetensi wirausaha yang derajatnya rendah maka sama artinya dengan peningkatan kompetensi wirausaha yang dibutuhkan petani

Hubungan Karakteristik individu

Dengan Kompetensi Wirausaha Petani $\underline{\text { Rumput laut }}$

Seluruh karakteritik individu yang diamati memiliki kesepakatan yang tinggi dalam menilai penjejangan semua bidang kompetensi wirausaha rumput laut. Hal itu ditunjukkan dengan koefisien konkordansi Kendal $W>0.851$ yang sangat nyata pada $\alpha$ $=0.01$ pada peubah pengalaman usaha dan peubah umur sebagai peubah karakteristik yang paling tinggi dengan koefisien Kendal $W=0,972$. seperti pada Tabel 1 .

Tabel 1. Hubungan Karakteristik Individu dengan

Kompetensi Wirausaha Responden

\begin{tabular}{|c|l|c|c|}
\hline \multirow{2}{*}{ No } & \multicolumn{1}{|c|}{ Peubah Karakteristik } & \multicolumn{2}{c|}{ Kompetensi wirausaha } \\
\cline { 3 - 4 } & & Koefisien Kendal W & Signifikansi \\
\hline $\mathbf{1}$ & Umur & $\mathbf{0 , 9 7 2}$ & $\mathbf{0 , 0 0 2} * *$ \\
\hline $\mathbf{2}$ & Pendidikan Formal (PF) & $\mathbf{0 , 9 2 7}$ & $\mathbf{0 , 0 0 3} * *$ \\
\hline $\mathbf{3}$ & Tanggungan Keluarga (Tangkel) & $\mathbf{0 , 9 4 9}$ & $\mathbf{0 , 0 0 2} * *$ \\
\hline $\mathbf{4}$ & Pendapatan Keluarga (PdkI) & $\mathbf{0 , 9 0 3}$ & $\mathbf{0 , 0 0 4} * *$ \\
\hline $\mathbf{5}$ & Pengalaman Usaha (PU) & $\mathbf{0 , 8 5 1}$ & $\mathbf{0 , 0 0 6} * *$ \\
\hline $\mathbf{6}$ & Motivasi Usaha (MU) & $\mathbf{0 , 9 5 0}$ & $\mathbf{0 , 0 0 2} * *$ \\
\hline $\mathbf{7}$ & Pemanfaatan Media Informasi (Pfmd) & $\mathbf{0 , 9 6 5}$ & $\mathbf{0 , 0 0 2} * *$ \\
\hline $\mathbf{8}$ & Luas Lahan Budidaya (LLh) & $\mathbf{0 , 9 4 1}$ & $\mathbf{0 , 0 0 3} * *$ \\
\hline $\mathbf{9}$ & Modal Usaha (MdU) & $\mathbf{0 , 9 5 4}$ & $\mathbf{0 , 0 0 2} * *$ \\
\hline
\end{tabular}


Tabel 1 di atas menjelaskan seluruh karakteristik individu petani rumput laut memiliki hubungan atau kesepakatan yang tinggi terhadap kompetensi wirausaha. Umur merupakan peubah yang memiliki kesepakatan tertinggi dibandingkan dengan peubah lain. Sedangkan peubah yang memiliki kesepakatan terendah adalah pengalaman usaha dan pendidikan formal dengan kategori sedang. Hubungan atau kesepakatan tersebut bearti terdapat kesesuai- an hubungan setiap karakteristik individu tersebut untuk dipertimbangkan sebagai faktor atau potensi pendukung dalam peningkatan kemampuan petani rumput laut.

Salah satu contoh dari analisis hubungan atau kesepakatan karakteristrik indicidu dalan penjenjangan Kompetensi wirausaha petani rumput laut dapat dilihat pada peubah umur pada Tabel 2 .

Tabel 2. Hubungan Umur dan Kompetensi Wirausaha Petani Rumput Laut

\begin{tabular}{|c|c|c|c|c|c|c|c|}
\hline \multirow{3}{*}{ No } & \multirow{3}{*}{ Bidang Kompetensi } & \multicolumn{6}{|c|}{ Umur } \\
\hline & & \multicolumn{2}{|c|}{ Muda } & \multicolumn{2}{|c|}{ Sedang } & \multicolumn{2}{|l|}{ Tua } \\
\hline & & ST & JJ & ST & JJ & ST & JJ \\
\hline 1 & panen & 3.21 & 1 & 3.13 & 1 & 3.23 & 1 \\
\hline 2 & komunikasi dan motivasi & 3.07 & 2 & 2.98 & 3.5 & 2.95 & 3 \\
\hline 3 & pembibitan dan penanaman & 3.06 & 3 & 2.98 & 3.5 & 3.1 & 2 \\
\hline 4 & pemilihan/penyed. lokasi & 2.96 & 4 & 3.07 & 2 & 2.89 & 4 \\
\hline 5 & mengorg dan memasarkan hasil & 2.85 & 5 & 2.77 & 5 & 2.78 & 5.5 \\
\hline 6 & mengambil kptsn,resiko dan bertindak kreatif & 2.83 & 6 & 2.74 & 6.5 & 2.72 & 7 \\
\hline 7 & Kem. pemeliharaan & 2.77 & 7 & 2.74 & 6.5 & 2.78 & 5.5 \\
\hline 8 & Kem. merencanakan & 2.63 & 8 & 2.58 & 8 & 2.54 & 8 \\
\hline 9 & Kem. mengelola pascapanen & 2.43 & 9 & 2.37 & 9 & 2.47 & 9 \\
\hline 10 & Kem. mengawasi, evaluasi dan pengengendalian & 2.24 & 10 & 2.28 & 10 & 2.2 & 10 \\
\hline
\end{tabular}

Keterangan $\mathrm{W}=0.972 \alpha=0.002$ Sangat nyata pada $\alpha=0 ., 01$

Uraian Tabel tersebut menunujukkan adanya perbedaan atau rega setiap kelompok petani berdasarkan karakteristiknya dalam penjenjangan kompetensi wirausaha. Pada kasus Tabel 2, walaupun ketiga kelompok umur petani rumput laut tersebut berbeda dalam memberi urutan prioritas kesepuluh bidang kompetensi wirausaha itu, namun koefisien Konkordansi Kendal $W$ sebesar 0,972 yang sangat nyata pada $\alpha=0.01$ menunjukkan bahwa ketiga kelompok petani tersebut sangat sepakat dalam penjejangan kesepuluh bidang kompetensi tersebut.

Kesepakatan yang dtunjukkan dengan koefisien Kendal W yang tinggi dapat diartikan bahwa di antara kelompok umur tidak memiliki keragaman yang terlalu berbeda dalam penjenjangan bidang-bidang kompetensi wirausaha yang ada. Hubungan atau kesepakatan yang tinggi tersebut berarti pada setiap karakteristik tidak memiliki keragaman yang terlalu berbeda. Hubungan atau kesepakatan dalam penjenjangan kompetensi wirausaha tersebut dapat diklasifikasikan dalam bidang kompetensi wirausaha yang tinggi dan kompetensi yang rendah seperti pada Tabel 3 .

Tabel 3 menjelaskan bahwa karakteristik umur dan sebagian karakteristik individu petani rumput laut lain terdapat kecenderungan umum yakni dari sepuluh kompetensi wirausaha ada tiga yang paling tinggi yakni (1) panen, (2) membibit dan menanam, dan (3) berkomunikasi dan memotivasi, sedangkan kompetensi wirausaha yang paling rendah adalah (1) merencanakan, (2) mengelola pasca panen, dan (3) mengawasi, evaluasi dan mengendalikan usaha. Pada analisis tersebut terdapat pula kecenderungan- kecenderungan yang bersifat khusus atau spesifik. 
Tabel 3. Bidang Kompetensi Wirausaha yang di Klasifikasikan Tinggi dan Rendah berdasarakan Skor Tertimbang dari Sembilan

Karakteristik Individu Petani

\begin{tabular}{|l|l|l|c|c|}
\hline No & Klasifikasi & \multicolumn{1}{|c|}{ Bidang Kompetensi } & $\begin{array}{c}\text { Jumlah Skor Tertimbang } \\
\text { dari Sembilan } \\
\text { Karakteristik Individu }\end{array}$ & $\begin{array}{c}\text { Skor } \\
\text { Tertimbang } \\
\text { Rata-rata }\end{array}$ \\
\hline 1 & Tinggi & Panen & 86,08 & 3,18 \\
\hline & & Komunikasi dan memotivasi & 81,45 & 3.02 \\
\hline & & Pembibitan dan penanaman & 80,64 & 2.99 \\
\hline 2. & Rendah & Merencanakan usaha & 71,16 & 2,63 \\
\hline & & Mengelola pasca panen & 65,30 & 2,41 \\
\hline & & Mengawasi, evaluasi dan pengendalian & 61,13 & 2,26 \\
\hline
\end{tabular}

Di samping analisis tersebut di atas, pada analisis lain dengan cara yang berbeda (Path analysis) setelah semua data dikonversi dilakukan pula uji pengaruh antar peubah karakteristik individu dengan kompetensi wirausaha, produksi dan pendapatan petani dari rumput laut untuk beberapa koefisien yang nyata, dapat dilihat pada Gambar 1.

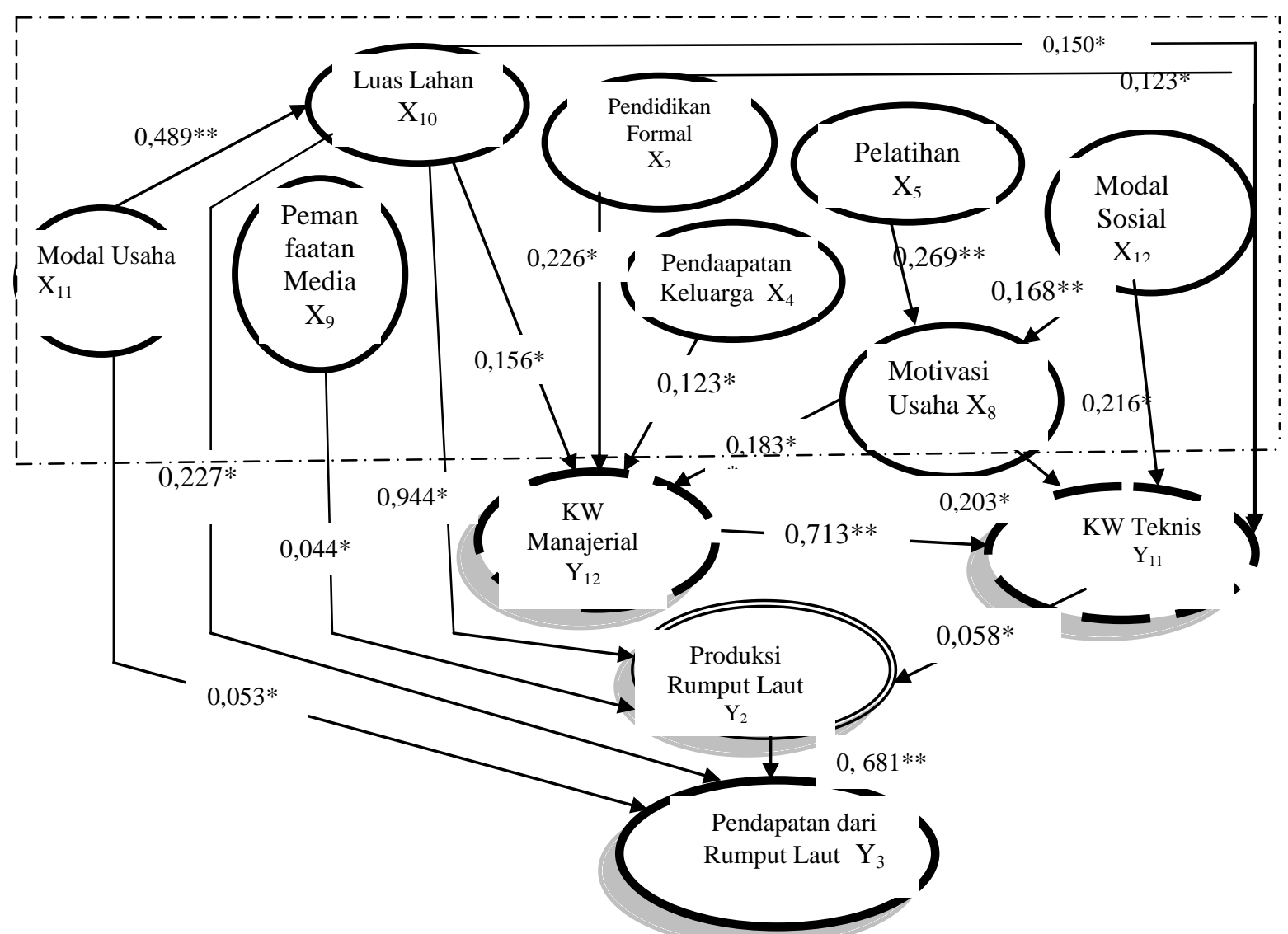

Gambar 1 Analisis Jalur (Path analysis) Peubah Karakteristik Individu yang Berhubungan dengan Kompetensi Wirausaha, Produksi dan Pendapatan Petani dari Rumput Laut

Uraian Gambar 1 yang telah dikonversi pada beberapa Tabel menjelaskan bahwa pertama, nilai pengaruh yang paling tinggi pada hubungan karakteritik individu dengan kompetensi wirausaha (KW) manajerial adalah akibat sumbangan pada pengaruh tidak langsung modal usaha melalui luas lahan sebesar 28,4 persen dan pengaruh langsung peubah pendidikan formal terhadap 
KW manajerial dengan sumbangan 22,2 persen. Selain itu atas sumbangan langsung pendapatan keluarga sebesar 12,3 persen, sumbangan pelatihan dan modal sosial melalui motivasi usaha masing -masing 12, 9 persen dan 12,7 persen.

Kedua, peubah motivasi usaha berpengaruh terhadap kompetensi wirausaha (KW) teknis baik secara (langsung dan tidak langsung) melalui $\mathrm{KW}$ manajerial dengan sumbangan 79,2 persen, selanjutnya pengaruh pendidikan formal (langsung dan tidak langsung) terhadap $\mathrm{KW}$ tehnis melalui $\mathrm{KW}$ manajerial dengan sumbangan 73,6 persen dan terakhir pengaruh $\mathrm{KW}$ manajerial (langsung) terhadap KW tehnis dengan sumbangan sebesar 71,3 persen.

Ketiga, sumbangan KW teknis secara langsung pada produksi rumput laut sangat kecil yakni hanya 5,8 persen, akan tetapi menjadi sangat besar jika berpadu dengan aspek manajerial yakni 55,4 persen. Sumbangan yang terbesar juga adalah akibat kontribusi atau sumbangan langsung dari luas lahan sebesar 94,4 persen Keempat, pendapatan petani banyak dipengaruhi oleh produksi rumput laut yang dihasilkan $(68,1)$ persen, bukan karena harga, kualitas atau faktor lain.

\section{Pembahasan}

Hasil penjenjangan kompetensi wirausaha dari sembilan karakteristik individu yang berkorelasi nyata dengan uji Kendall W, terdapat kecenderungan umum seperti: panen, membibit dan menanam, komunikasi dan memotivasi pada urutan tertinggi. Hal itu disebabkan ketiga bidang tersebut umumnya dilakukan petani sesuai kebiasaan pada setiap siklus produksi dan ketiga bidang kompetensi tersebut tidak menuntut inovasi yang rumit selain mudah dilakukan, sedangkan kompetensi wirausaha yang rendah (merencanakan, mengelola pascapanen dan mengawasi, evaluasi dan mengendalikan usaha) bermakna sebaliknya yakni jarang sekali dilakukan oleh petani karena memerlukan pemahaman, keterampilan dan unsur inovasi, motivasi dan daya kreatifitas yang lebih tinggi.

Karakteristik individu petani rumput laut memiliki hubungan atau kesepakatan yang tinggi dalam penjenjangan sepuluh kompetensi wirausaha. Umur merupakan peubah yang memiliki kesepakatan tertinggi dibandingkan dengan peubah lain. Sedangkan peubah yang memiliki kesepakatan terendah adalah pengalaman usaha dan pendidikan formal dengan kategori sedang. Hubungan atau kesepakatan yang tinggi tersebut berarti pada setiap karakteristik tidak memiliki keragaman yang terlalu berbeda, sehingga dapat dimaknai, mereka mempunyai persepsi yang sama mengenai sepuluh bidang kompetensi tersebut dan terdapat kesesuaian hubungan setiap karakteristik individu tersebut untuk dipertimbangkan sebagai faktor atau potensi pendukung dalam peningkatan kemampuan petani rumput laut.

Kecenderungan yang bersifat khusus lebih menekankan perbedaan masing-masing kelompok pada setiap karakteristik yang ditandai dengan keunggulannya masing masing. Pada beberapa karakteristik individu petani rumput laut kelompok petani usia muda, kelompok Pendidikan Formal tinggi, kelompok tanggungan keluarga banyak, kelompok Pendapatan keluarga rendah dan sedang, kelompok motivasi usaha sedang dan kelompok Modal usaha tinggi memberi apresiasi yang lebih tinggi pada aspek pengambilan keputusan, menanggung resiko dan bertindak kreatif walaupun secara keseluruhan aspek ini diklasifikasikan pada bidang $\mathrm{KW}$ yang kurang dianggap penting (Jenjang ke-5). Hal itu disebabkan karena pada kelompok-kelompok tersebut mulai terdapat sikap-sikap yang mengarah kepada kesiapan diri yang bersifat inovatif terkait dengan aspek keputusan, resiko dan kreatifitas walaupun masih pada tingkatan yang rendah.

Pada kelompok pendidikan formal tinggi, kelompok pengalaman usaha lama dan kelompok luas lahan budidaya luas, menganggap kemampuan komunikasi dan memotivasi pada urutan jenjang pertama. Hal 
tersebut disebabkan karena pada kelompok petani rumput laut tersebut sesuai pendidikan, pengalaman dan status sosial mereka telah terjadi pergeseran pola pikir selaku juru tani kepada aspek manajerial dan menempatkan aspek tersebut sebagai urutan penting dalam kompetensi wirausaha (KW) tanpa mengurangi perhatian pada aspek teknis. Kemampuan teknis mengenai memilih dan menyediakan lokasi, pemeliharaan dan aspek pengorganisasian dan pemasaran hasil bagi semua karakteristik individu berada pada urutan jenjang sedang, memberi arti ketiga kemampuan tersebut belum menjadi perhatian utama, tetapi sudah mulai menjadi urutan yang lebih tinggi pada pandangan petani dibandingkan dengan tiga kemampuan yang telah disebutkan di atas.

Rangkuman penjelasan dari uraian sebelumnya adalah bahwa kecenderungan tersebut disebabkan petani rumput laut pada semua kelompok karakteristik individu masih bekerja berdasarkan naluri, berusaha tani karena ingin mendapatkan rasa aman atau mengutamakan keselamatan, berpatokan pada kebiasaan dan sangat tergantung pada kemurahan alam. Hal tersebut yang menjadi sebab petani lemah pada perencanaan, pengawasan, evaluasi dan pengendalian. Petani juga mengalami kelemahan pada teknologi, pengetahuan dan keterampilan sehingga menyebabkan mereka lemah pada pengelolaan pascapanen.

Pada analisis lain dengan menggunakan Path analysis, beberapa karakteristik individu memiliki pengaruh atau sumbangan yang besar terhadap terhadap kompetensi wirausaha (manajerial petani) dan selanjutnya berpengaruh pada kompetensi teknis. Sumbangan terbesar akibat pengaruh beberapa peubah karakteristik individu petani seperti pendidikan formal, luas lahan, pelatihan, modal sosial dan motivasi usaha. Pengaruh tersebut memberi arti bahwa pada kasus petani rumput laut telah berkembang sedemikian rupa berbagai aktifitas yang berhubungan, beberapa karakteristik tersebut pada petani yang mewarnai aspek kemampuan manajerialnya sebagai pendorong inovasi di bidang teknis budidaya dan selanjutnya kepada produksi.

Peubah motivasi usaha berpengaruh terhadap kompetensi wirausaha (KW) teknis baik secara langsung dan tidak langsung melalui KW manajerial dengan sumbangan 79,2 persen, selanjutnya pengaruh pendidikan formal (langsung dan tidak langsung) terhadap $\mathrm{KW}$ teknis melalui $\mathrm{KW}$ manajerial dengan sumbangan 73,6 persen dan terakhir pengaruh KW manajerial (langsung) terhadap KW teknis dengan sumbangan sebesar 71,3 persen. Ketiga pengaruh tersebut berarti:

Pertama, peningkatan kompetensi wirausaha teknis berkembang di kalangan petani melalui peningkatan motivasi usaha guna meningkatkan kemampuan pada kompetensi manajerial, yang sebelumnya motivasi usaha tersebut dipengaruhi oleh pelatihan. Fakta menunjukkan bahwa pelatihan yang berkembang di kalangan petani walaupun hanya diikuti oleh sebagian kecil petani saja atau 2,9 persen dari jumlah petani, namun demikian nilai pelatihan tersebut telah memberi motivasi besar kepada petani untuk mengembangkan rumput laut. Motivasi tersebut selanjutnya mempengaruhi kompetensi wirausaha manajerial dan sekaligus mempengaruhi kompetensi wirausaha tehnis dikalangan petani.

Pengaruh lain adalah dari modal sosial sebesar 21,6 persen (gambar1). Pengaruh tersebut dapat dipahami bahwa rumput laut dikalangan petani berkembang sedemikian rupa atas dasar saling percaya melalui jaringan sosial yang berlangsung secara alamiah oleh karena sebahagian besar petani mengembangkan rumput laut berdasarkan kepercayaan mereka terhadap infomasi pedagang pengumpul dan tetangga, kerabat atau keluarga (94,9 persen).

Pada kasus usaha rumput laut, harus diakui bahwa jaringan sosial tersebut tumbuh di kalangan petani rumput laut akibat pengaruh nilai atau prinsip sosial pada suku Bugis Makassar yang di kenal dengan "a bulo sibattang, a cera sitongka-tongka" (menyatu seperti sebatang bambu karena merasa senasib dan sepenanggungan), dan nilai budaya lain 
yakni " sipakatau" (saling menghargai). Walaupun pada tahap berikutnya komoditas ini dinilai menguntungkan dan memberi tambahan pendapatan sehingga motivasi utama di kalangan petani dalam mengembangkan komoditas rumput laut adalah motivasi intrinsik antara lain guna memenuhi kebutuhan pokok dan meningkatkan pendapatan sekitar 96,1 persen, dan selebihnya karena didorong oleh keinginan untuk menguasai seluk beluk usaha rumput laut dan karena ingin memperoleh harga yang lebih terjamin.

Kedua, sumbangan berikut adalah pendidikan formal (langsung dan tidak langsung) melalui kompetensi wirausaha (KW) manajerial. Sumbangan tersebut sejalan dengan yang telah dijelaskan sebelumnya bahwa jumlah petani yang berpendidikan formal lebih tinggi ikut memberi pengaruh berkembangnya kompetensi wirausaha manajerial di kalangan petani. Tetapi pada nilai pengaruh tidak langsung pendidikan formal terhadap KW teknis, merupakan akibat kontribusi yang besar dari kompetensi wirausaha $(\mathrm{KW})$ manajerial.

Ketiga, sumbangan KW manajerial terhadap KW teknis sekitar 71,3 persen pada kasus usahatani rumput laut memberi makna bahwa kemampuan teknis berupa inovasi yang berkembang pada petani bukanlah karena pemberian input teknologi seperti yang umumnya terjadi, akan tetapi lebih disebabkan oleh aspek manajerial antara lain seperti komunikasi dan memotivasi, mengambil keputusan, mengambil resiko dan tindakan kreatif dalam memecahkan masalah yang mereka hadapi di wilayah pesisir. Berkaitan dengan motivasi, pada suku Bugis Makassar terdapat prinsip " kualengi talianga na to alia" artinya sekali meyakini sesuatu, harus diusahakan tercapai, atau dalam pepatah "sekali layar terkembang pantang biduk surut ke pantai", dan tentang kerja "resopa tamangingi na lette pammase" artinya hanya kerja keras yang diridhoi Tuhan Yang Maha Kuasa.

Sebagaimana diketahui, pada budidaya rumput laut perairan petani melakukan aktifitasnya dituntut untuk berani dan teguh menghadapi arus dan gelombang serta kedalaman pantai, yang penuh dengan resiko-resiko yang memerlukan kepekaan. Kepekaan-kepekaan tersebut umumnya berumber dari kaidah-kaidah manajerial. Namun demikian berdasarkan informasi sebelumnya, bidang kompetensi manajerial merencanakan, mengawasi, evaluasi dan mengendalikan usaha merupakan bidang kompetensi yang berada pada jenjang yang rendah. Kedua bidang kompetensi ini perlu menjadi perhatian di masa mendatang. Sejalan dengan penjelasan tersebut, walaupun petani memiliki kompetensi teknis akibat pengaruh kompetensi manajerial, akan tetapi berdasarkan penjenjangan, bidang kompetensi teknis yang tertinggi adalah panen, membibit dan mananam, merupakan bidang kompetensi yang mudah dilakukan atau tidak dituntut inovasi yang rumit atau kecanggihan teknologi, akan tetapi petani lemah pada bidang pascapanen.

Sumbangan KW teknis secara langsung pada produksi rumput laut sangat kecil yakni hanya 5,8 persen, akan tetapi menjadi sangat besar jika berpadu dengan aspek manajerial yakni 55,4 persen. Sumbangan yang terbesar juga adalah akibat kontribusi atau sumbangan langsung dari luas lahan sebesar 94,4 persen. Luas lahan dimaksud harus dilihat pada kepastian pemilikan dan penggunaannya. Kepastian lahan itu dapat diartikan berupa kepastian luas, kepastian pemilikan investasi serta kepastian dalam penggunaannya seperti memiliki izin, barang modal berupa tali bentangan, plampung dan sebagainya, walaupun 88,9 persen petani mengakui lahan budidaya tersebut milik sendiri tetapi barang modal umumnya masih merupakan pinjaman dari pihak lain. Sumbangan lain yang perlu dipertimbangkan pula walaupun kecil $(4,4$ persen) adalah akibat pengaruh pemanfaatan media informasi. Setidak-tidaknya informasi melalui media masa tentang kegunaan atau manfaat rumput laut, peluang rumput laut sebagai salah satu alternatif yang memberi keuntungan kepada petani menjadi pendorong 
bagi mereka untuk meningkatkan produksinya.

Keempat, pendapatan petani banyak dipengaruhi oleh produksi rumput laut yang dihasilkan $(68,1)$ persen, bukan karena harga, kualitas atau faktor lain. Secara tidak langsung sumbangan tersebut juga cukup besar jika produksi rumput laut, berpadu dengan kemampuan pada $\mathrm{KW}$ teknis dan $\mathrm{KW}$ manajerial yang sebelumnya banyak dipengaruhi oleh motivasi usaha yang lebih besar pula.

Implikasi dari seluruh penjelasan di atas adalah (1) Tiga karakteristik individu petani rumput laut seperti: (a) umur, (b) pendidikan formal dan (c) pengalaman usaha dapat dijadikan pertimbangan sebagai alat identifikasi jika kelak terdapat upaya intervensi guna mengatasi masalah yang dihadapi petani dan karakteristik lain dapat menjadi pendukung untuk maksud tersebut (2) Tiga bidang kompetensi yang memiliki urutan tertinggi pada penjenjangan (a) panen (b) pembibitan dan penanaman (c) berkomunikasi dan memotivsi merupakan ukuran kualitas, bentuk perilaku atau kemampuan yang terbaik pada petani tetapi masih perlu ditingkatkan sedangkan tiga bidang lain yang paling rendah (a) perencanaan (b) mengelola pascapanen dan (c) pengawasan, evaluasi dan pengendalian, perlu diberi perlakuan khusus melalui diseminasi, pelatihan, pendampingan dan teknik pendidikan (penyuluhan) lain yang sesuai dengan potensi dan kebutuhan petani. (3) Sikap positif dan kemampuan lain yang telah tumbuh pada beberapa kelompok petani merupakan potensi penting sebagai pertimbangan untuk memahami kondisi dan karakteristik petani rumput laut khususnya dan masyarakat pesisir umumnya.

Pemahaman tersebut memudahkan pihak lain merancang tindakan yang tepat guna membantu petani. (4) Beberapa karakteristik individu petani berhubungan nyata dengan bidang-bidang kompetensi wirausaha. Hubungan tersebut menunjukkan semakin tinggi perubahan pada setiap karakteristik individu petani rumput laut semakin besar kemungkinan perubahan yang terjadi pada setiap bidang kompetensi wirausaha petani tersebut, baik itu kompetensi yang bersifat teknis maupun yang bersifat manajerial. Artinya tinggi rendahnya bidangbidang kompetensi wirausaha petani ditentukan pula oleh peningkatan karakteristik individu mereka (5) Beberapa karakteristik individu petani berhubungan nyata dengan bidang-bidang kompetensi wirausaha, dibuktikan dengan adanya pengaruh beberapa karakteristik individu seperti pendidikan formal, pendapatan keluarga, pelatihan, luas lahan, modal usaha, modal sosial dan motivasi terhadap kompetensi wirausaha, berupa sumbangan langsung maupun tidak langsung, selanjutnya berpengaruh terhadap peningkatan produksi dan pendapatan petani dari rumput laut, sehingga dalam meningkatkan kapasitas petani perlu (1) mempersiapkan program penyuluhan yang bersifat terpadu guna menggerakkan motivasi usaha dan meningkatkan kompetensi wirausaha (2) mendorong adanya kebijakan pemerintah, agar petani memiliki kepastian dalam investasi, penguasaan dan penggunaan lahan guna meningkatkan produksi dan pendapatannya dari rumput laut.

Bagi petani rumput laut perlu dibangkitkan motivasi, semangat dan kesadaran baru sehingga petani dapat mengenal dengan lebih mendalam masalah yang dihadapi pada lingkungannya, demikian pula dengan potensi yang ada pada dirinya. Pemahaman terhadap kedua hal tersebut dapat menjadi landasan dalam membangun pola pikir baru yang selalu memandang pencapaian tujuan yang jauh ke depan menjadi sesuatu yang niscaya.

Petani perlu mengenal kemampuankemampuan yang berhubungan langsung dengan tugas kerjanya dan meninggalkan sifat-sifat lama seperti putus asa dan terpaku pada rutinitas, menghindari kualitas karena mendahulukan keamanan, melakukan sesuatu tanpa harapan-harapan dan lain-lain, menjadi perilaku baru yang lebih cerdas, yang berpatokan pada mental disiplin, kepeloporan dan keteladanan, motivasi yang tinggi, membuka peluang dengan penuh perhitungan, 
menghasilkan produk yang bersaing dan disukai pasar. Perilaku tersebut memungkinkan petani rumput laut melaksanakan tugasnya dengan lebih kompeten.

\section{$\underline{\text { Kesimpulan }}$}

1. Karakteristik individu petani rumput laut pada penelitian ini mayoritas berumur muda ( $<44$ tahun), pendidikan formal umumnya rendah ( $<9$ tahun), tanggungan keluarga sedang (3 orang), pendapatan keluarga < Rp 693 000, pengalaman usaha sedang, motivasi usaha sedang, pemanfaatan media rendah, luas lahan budidaya sempit $(<7500 \mathrm{~m} 2)$ dan modal usaha tergolong sedang.

2. Tiga bidang kompetensi yang memiliki urutan tertinggi pada penjenjangan kompetensi wirausaha adalah: (a) panen (b) pembibitan dan penanaman (c) berkomunikasi dan memotivasi merupakan ukuran kualitas, bentuk perilaku atau kemampuan yang terbaik pada petani tetapi masih perlu ditingkatkan. Sedangkan tiga bidang lain yang paling rendah ialah: (a) perencanaan (b) mengelola pasca panen dan (c) pengawasan, evaluasi dan pengendalian, perlu diberi perlakuan khusus melalui diseminasi, pelatihan, pendampingan dan teknik pendidikan (penyuluhan) lain yang sesuai dengan potensi dan kebutuhan petani.

3. Derajat hubungan keseluruhan karakteristik individu petani rumput laut menunjukkan kesepakatan yang tinggi $(\alpha=0,01)$ dalam penjenjangan seluruh bidang kompetensi wirausaha yang diamati, yang berarti terdapat kesesuaian hubungan setiap karakerteritik individu tersebut untuk dipertimbangkan sebagai faktor pendukung dalam peningkatan kemampuan petani rumput laut.

4. Karakteristik individu seperti pendidikan formal, pelatihan, modal sosial, motivasi, modal usaha dan luas lahan memiliki hubungan atau pengaruh yang nyata terhadap kompetensi wirausaha, yang berpengaruh pula terhadap peningkatan produksi dan pendapatan petani sehingga dalam meningkatkan kapasitas petani perlu: (1) mempersiapkan program penyuluhan yang bersifat terpadu guna menggerakkan motivasi usaha dan meningkatkan kompetensi wirausaha (2) mendorong adanya kebijakan pemerintah, agar petani memiliki kepastian dalam investasi, penguasaan dan penggunaan lahan guna meningkatkan produksi dan pendapatannya dari rumput laut.

\section{$\underline{\text { Rujukan }}$}

Ditjen Perikanan Budidaya, 2005 Profil Rumput Laut Indonesia. Jakarta: Departem Kelautan dan Perikanan. , 2006 Petunjuk Tehnis Budidaya Laut, Rumput Laut Eucheuma, spp. Jakarta: Departemen Kelautan dan Perikanan.

Gilley, J.W. \& S.A.Egland, 1989. Principle of Human Resources Development, Addison -Wesley Publishing Company, Inc.

Indriani, H, E. Sumiarsih 2005 Budidaya, Pengolahan dan Pemasaran Rumput Laut. Jakarta: Penebar Swadaya.

Jahi, A. 1988 Komunikasi Massa dan Pembangunan Pedesaan di NegaraNegara Dunia ke Tiga. Jakarta: PT Gramedia.

Mardikanto, T 1992 Penyuluhan Pembangunan Pertanian. Surakarta: Sebelas Maret University Press.

Meredith, G.G, R.E Nelson, P.A Neck, 2000 Kewirausahaan. Teori dan Praktek. Jakarta: Lembaga Manajemen PPM dan Pustaka Binaman Presindo.

Mosher, A.T 1983 Menggerakkan dan Membangun Pertanian. Syarat-Syarat Pokok Pembangunan Modernisasi. Terjemahan. Jakarta: CV Yasaguna.

Spencer, L.M., S.M. Spencer, 1993 Competence at Work. New York: Chishster, Brisbane, Toronto, Singapore: John Wiley \& Sons, Inc. 